\title{
Article \\ Sentiment-Augmented Supply and Demand Equations for the Dry Bulk Shipping Market
}

\author{
Nektarios A. Michail ${ }^{1,2,3, *}$ and Konstantinos D. Melas ${ }^{3,4}$ (D) \\ 1 Economic Analysis and Research Department, Central Bank of Cyprus, Nicosia 1076, Cyprus \\ 2 Department of Commerce, Finance, and Shipping, Cyprus University of Technology, Limassol 3036, Cyprus \\ 3 Cyprus Centre for Business Research, Nicosia 1100, Cyprus; constantinosmela@hotmail.com \\ 4 Faculty of Business and Economics, Metropolitan College, 54624 Thessaloniki, Greece \\ * Correspondence: nektariosmichail@centralbank.cy
}

Citation: Michail, Nektarios A., and Konstantinos D. Melas. 2021.

Sentiment-Augmented Supply and Demand Equations for the Dry Bulk Shipping Market. Economies 9: 171. https://doi.org/10.3390/

economies 9040171

Academic Editor: Franklin G. Mixon

Received: 7 September 2021

Accepted: 29 October 2021

Published: 5 November 2021

Publisher's Note: MDPI stays neutral with regard to jurisdictional claims in published maps and institutional affiliations.

Copyright: (c) 2021 by the authors. Licensee MDPI, Basel, Switzerland. This article is an open access article distributed under the terms and conditions of the Creative Commons Attribution (CC BY) license (https:// creativecommons.org/licenses/by/ $4.0 /)$.

\begin{abstract}
We present, for the first time in the literature, empirical estimates of the supply and demand curves for the ocean-going dry bulk sector, using a three-stage least squares methodology. Furthermore, we augment these functions with sentiment, which appears to have a positive and significant impact on supply. This supports the view that the outlook that shipowners have about the market will undoubtedly influence their decisions regarding purchasing vessels or bringing them out of lay up. Thus, our results highlight the fact that future expectations have an impact on current pricing, albeit indirectly, through their impact on the supply side. Our results further enhance the behavioral economics literature and provide important insights for both academics and professionals.
\end{abstract}

Keywords: shipping markets; demand; supply; sentiment; dry bulk; three-stage least squares

\section{Introduction}

Seaborne trade accounts for more than the $80 \%$ of goods transported globally (UNCTAD 2019), thus its importance it is not solely entrenched in the maritime economics field. Various studies have already shown that the shipping industry has an indicative leading role both in world economy (Kilian 2009; Kilian and Zhou 2018; Hamilton 2019; Funashima 2020) as well as in the international stock markets (Kilian and Park 2009). Thus, the forces that are affecting the industry are of interest not only to shipping investors per se, but also to the wider economy.

The current literature has already provided insights with regard to the basic demand and supply functions in the maritime industry. Koopmans (1939) was the first to describe the demand for sea-going transportation as a derived demand system, i.e., that demand for the transported goods affects the demand for shipping, as there is no demand for shipping per se. Following this, various researchers have tried to establish a holistic approach to the supply and demand equilibrium. Zannetos (1959) was the first to use empirical findings in his research thesis, and provided some preliminary results on supply and demand for the tanker market.

After these two seminal contributions, and since the 1980s, the literature has focused more on the inelastic nature of the demand for the shipping industry, and has tried to answer questions on the equilibrium price of freight rates (see Hawdon 1978; Beenstock and Vergottis 1989, 1993). More recently, Ådland and Strandenes (2007) have used a stochastic extension of the partial equilibrium models and have calculated the equilibrium prices of the spot charter rates in the Very Large Crude Carrier (VLCC) market.

Until now, empirical findings have shown that demand is affected by the world economy, the commodity trades that are taking place globally, the demand for transportation given the complex matrix of cargo that will be transported and the distance covered, exogenous economic shocks and, finally, transportation costs. Recent studies by Michail (2020) and Strandenes and Thanopoulou (2020) presented empirical evidence on the relationship 
between shipping demand and the world economy. On the supply side of the equation, the main variables appear to be world fleet, fleet productivity, which is measured in ton-miles (i.e., the cargo transported multiplied by the speed of the vessels), shipbuilding production, scrapping and losses, and, finally, freight revenues. ${ }^{1}$

Nevertheless, as Stopford (2013) noted, other than price, which in this case is the freight rate (commonly accepted to impact both demand and supply), there is an additional variable that acts as a catalyst for both the supply and demand functions, and eventually for their equilibrium price. That variable is market sentiment. While previous studies have given much insight into the dynamics of the demand and supply of shipping freight rates, the role of market sentiment in supply and demand has not yet been empirically studied.

The research is fruitful when it comes to behavioral aspects that are entrenched in the investment decisions of the shipowners. The main reasons that shipowners rely heavily on their intuition for their investment decisions is, initially, the high volatility of the market (Tsouknidis 2016), the positive skewness exhibited in the risk-return relationship (Theodossiou et al. 2020) and the high risk exposure of the industry (Melas and Michail 2021). The three reasons listed in the previous sentence appear to drive shipowners to trust their intuition when it comes to investment decisions, given that accurate future returns cannot be ex ante statistically calculated.

Initially, it was Papapostolou et al. (2014) who provided evidence on the existence of shipping market sentiment and its relationship with contrarian trading strategies in the dry bulk market. In their research, they quantified the sentiment index for the dry bulk market for the period between January 1976 and January 2012. In a follow-up study, Papapostolou et al. (2016) showed that qualitatively similar results hold for the tanker and the containership markets. More recently, Melas et al. (2020) provided evidence of the market fundamentals that affect the sentiment of the market.

The effects that sentiment have on the decisions of shipowners are two-way. Positive sentiment during freight auctions will lead shipowners to either ask for higher prices or try to negotiate their services for the spot market, given that they expect that freight rates will increase in the future. On the contrary, negative sentiment will lead shipowners to be more prudent and try to hire their vessels for longer periods of time. Additionally, one should notice if exogenous shocks are affecting the sentiment in the short or the long term. If shocks have only a short-term effect, volatility in the freight rates will be exhibited (Zannetos 1959). On the contrary, if shocks have a long-term effect, shipowners will further decide on their fleet mix (Michail and Melas 2021). However, while the impact of sentiment has been thoroughly studied in the realms of economics (Kahneman et al. 1986) and finance (see Thaler 1985; Lee et al. 1991; Chiang and Zheng 2010), research in transportation economics remains scant.

Papapostolou et al. (2014) were the first to quantify shipping market sentiment by employing a dataset from the dry bulk sector. In their research, they additionally found that sentiment is a statistically significant and contrarian indicator of future vessel price returns. In addition to this research, Papapostolou et al. (2016) showed that sentiment is also apparent in the tanker and the containership sectors, in addition to the dry bulk sector. Furthermore, they provided evidence of the significance of tanker sentiment as a contrarian global predictor of financial assets in an in- and out-of-sample framework.

Nevertheless, while the shipping finance literature has studied how sentiment can act as an investment indicator for the industry, a gap in the literature exists when it comes to the actual effect that sentiment can have in an equilibrium setting with regard to prices in shipping markets. Going back to the Keynesian theory that equilibrium aggregate supply is determined by aggregate demand and thus influenced by sentiment (Keynes 1936; Angeletos and LaO 2013; Benhabib et al. 2017), research in other industries has shown that this relationship stands up in empirical testing (see Jin et al. (2014) for the real estate market, Gao and Süss (2015) for commodities and Deeney et al. (2015) for the oil market).

Thus, in the current research, other than presenting current empirical estimates of supply and demand curves for the sea transport sector, we also augment them, again for 
the first time in the literature, with market sentiment to study the impact it can have on the supply and demand functions of the dry bulk market, and subsequently to freight rates. Our research strengthens our knowledge of the market dynamics that exist in the shipping industry by putting the various determinants of the equilibrium price (i.e., freight rates) in the context of supply and demand functions.

The current research benefits the literature in various ways. First, as already suggested, an updated empirical estimate of the supply and demand functions in shipping is offered. Second, the introduction of sentiment allows us to quantify its impact on freight rates and further expands our knowledge about the maritime industry. Third, based on the above, we can, for the first time, empirically assess and analyze the conceptual model of supply and demand as described by Stopford. Finally, the current research introduces the three-stage least squares model, which provides the best setting for an exploration of demand and supply equations (Amemiya 1977; Zellner and Theil 1962) and is a methodology that has been little used in the maritime industry (Luo et al. 2009). Furthermore, our results are crucial not only for shipowners who can predict the equilibrium price of the market, but also for the charterers who want to transfer their goods. Finally, our results are of use to the broader spectrum of the maritime industry (i.e., countries, shipyards, shareholders) in that they can compute any off-equilibrium deviations and take the actions required to improve their respective positions.

Following this introduction, the remainder of this paper is organized as follows: Section 2 provides a review of the literature on the issue, Section 3 describes the methodology and the data used, Section 4 discusses the empirical results obtained and Section 5 makes conclusions on the findings.

\section{Literature Review}

Shipping has served as a fruitful setting for behavioral studies given its volatile nature (Scarsi 2007; Alexandridis et al. 2018). The overall literature in the field lies primarily in three different pillars of behavioral research, namely over-extrapolation, herding behavior and sentiment.

The first researcher that pointed out a standard practice that is used by shipowners was Zannetos (1959), who implied that an extrapolation of the existing fundamentals takes place when investment decisions are taken. Interestingly, the first conceptual justification of such an extrapolation was made much later, by Tversky and Kahneman (1974). In the following years, both Metaxas (1971) and Beenstock and Vergottis (1989) looked into the matter; however, the limited availability of data curtailed their ability to reach concrete conclusions on the results of the extrapolating behavioral bias of shipowners. In addition, Bulut et al. (2013) similarly suggested that shipping companies are more prone to invest during the boom of the cycle, and consequently have a drop in their return on equity.

More recently, Alizadeh and Nomikos (2007) employed a dataset of monthly data for 28 years and showed that co-integrating techniques can be more useful for shipping investors, again showcasing that fundamentals play an important role. These results are complemented by Michail and Melas (2019), who showed that a co-integrating technique based on fundamentals is also useful for stock trading purposes.

Finally, in the same spirit as the previous research, is the study by Greenwood and Hanson (2015). In their research, they provided theoretical evidence of the extrapolation of fundamentals by the shipowners. More precisely, they showed that shipping investors extrapolate the exogenous demand shocks, and thus more vessels are ordered, creating an endogenous shock. However, given the time lag between ordering and receiving a vessel that exists intrinsically in the shipping industry, investors become disappointed and thus create a shorter than average business cycle.

More recently, Moutzouris and Nomikos (2020) developed a conceptual behavioral model for the handysize dry bulk vessel market. Regarding extrapolation, Greenwood and Hanson (2015) hypothesized about a system where the shipping investors are either conservatives or extrapolators. Their results suggest that a market where a small fraction 
of the agents overextrapolate can explain the positive relationship between earnings, vessel prices and trading activity. Nevertheless, empirical studies on the topic remain scarce.

In a similar stream in the literature, research has focused on the herding behavior of investors, where "herding" is defined as the imitation of actions between investors/economic agents (Spyrou 2013). This can take place either intenionally, due to an asymmetry of information, or unintentionally, due to the same information that investors share (Krokida et al. 2020).

Herding behavior is largely what causes the boom-bubble-bust cycle in the shipping industry, according to Duru (2013), while herding behavior also exists in newbuilding contracts and scrapping in the industry (Papapostolou et al. 2017). More precisely, the latter study looks into the dry bulk sector, and identifies that unintentional herding is apparent. Moreover, in the lower parts of the business cycle, unintentional herding is more statistically significant with regard to scrapping. This means that, given the same information on the market, shipowners will tend to act similarly, and thus decide to scrap in order to minimise the excess vessel capacity in the market. Intentional herding, while apparent in the research, is scarce, and it seems that there are very few older generation established shipowners that are mimicked by the rest of the investors.

In a similar context, Lee and Yip (2018) also concluded that herding behavior exists in the shipping industry when studying the building of new vessels in Korea. They documented that unintentional herding was apparent in the country in the period between April 2003 and September 2009. Finally, Syriopoulos and Bakos (2019) provided evidence that the herding behavior that it is apparent in shipping businesses is also reflected in their stocks.

As already disscussed in the introduction of this paper, Papapostolou et al. $(2014,2016)$ were the first to introduce the idea of market sentiment in the shipping industry, and by quantifying it, they have shown its implications both as a trading strategy for vessels as well as a leading indicator of shipping stocks. The current research builds on these findings and extends the previous literature by establishing the economic relationship between sentiment and demand and supply for sea-going transportation services.

\section{Methodology and Data}

\subsection{Estimating Sentiment}

Measuring sentiment, whether it is for whole markets or for specific sectors such as shipping, is not easily conducted, given that there is no universal consensus on the proxies that one should be using (Schmeling 2009). Nevertheless, specifically for the shipping market, Papapostolou et al. $(2014,2016)$ provided five proxies that are an indication of the level of pessimism or optimism that may prevail at a given point in time, either in the tanker, the dry bulk or the containership sectors.

These five proxy variables fall into three categories: (1) market expectations; (2) valuation; and (3) liquidity. Market expectations are measured by net contracting, and the money committed to proxies that take into consideration the change in the orderbook and amount of funds committed to these new vessels. Valuation is measured by the price-to-earnings and the second-hand-to-newbuilding price ratio, which offers a view of the valuations that are present in the industry. Finally, liquidity is measured by the turnover proxy, i.e., how fast sales transactions are taking place compared to the overall fleet. Given that these proxies are now standard in the literature, we abstain from offering more details for the sake of brevity. The interested reader may refer to Papapostolou et al. $(2014,2016)$ for more details.

After calculating the proxies, using data from March 1995, we followed the procedure suggested by Papapostolou et al. $(2014,2016)$ and orthogonalized them, one by one, in order to exclude the impact of any macroeconomic factors from the non-sentiment part (i.e., the world economy part). To do so, we regressed each proxy with three variables: (i) industrial production growth for the US as a proxy for the world's GDP; (ii) a dummy variable for the recession periods of G7 (monthly); and (iii) a dummy variable for the 
recession periods of the five major Asian countries. To obtain results that were qualitatively similar, we used year fixed effects in the orthogonalizing process.

After said regressions were estimated, we employed their residuals, given that this is the part of the proxy that is not explained by macroeconomic, fundamental factors and can thus be viewed as a proxy for sentiment. To avoid any potential one-off events, the final stage of the estimation process used the Hodrick-Prescott filter on the residuals in order to smooth them out.

After this process, in accordance with Papapostolou et al. $(2014,2016)$, we proceeded with a principal component analysis, using the contemporaneous value of the proxy, as well as its one-month and two-month lags. Thus, given the five proxies and their lags, we obtained an initial principal component matrix of 15 variables. With these, we calculated the first principal component and, in order to estimate which variables would be included in the final equation for the sentiment index and at which lag, we calculated the correlation between the first principal component and each of the 15 variables. For each proxy, the value that had the highest correlation with the principal component entered the final estimation for the sentiment index. As such, the sentiment index included one value from each of the five previously described proxies, which were then weighted using the first principal component of the selected proxies.

\subsection{Estimating Supply and Demand}

Once the sentiment index had been constructed, we moved to estimate the supply and demand functions, using a three-stage least squares (3SLS) methodology as proposed by Zellner and Theil 1962. ${ }^{2}$ In particular, the 3SLS methodology estimates a system of structural equations, whereby some of them contain endogenous variables among the explanatory variables. Endogenous variables are (typically) dependent variables from other equations in the system. The difference from the usual least squares regression, as well as from the two-stage least squares (2SLS) estimator, is that the 3SLS method combines the two in the sense that exogenous variables are taken as instruments for the endogenous variables (similar to two-stage least squares), which are then regressed to reach the final specification, similar to a least square estimation.

Before we introduced the 3SLS estimator, we first proposed the use of the following supply (Equation (1)) and demand (Equation (2)) functions:

$$
\begin{gathered}
V_{t}=c_{1}+a_{1} V_{t-1}+a_{2} B D I_{t}+a_{3} S_{t}+\varepsilon_{t} \\
D_{t}=c_{2}+b_{1} D_{t-1}+b_{2} B D I_{t}+b_{3} S_{t}+b_{j} \sum_{j=4}^{J} \operatorname{Prod}_{t}
\end{gathered}
$$

where $V_{t}$ refers to the deadweight tonnage of the vessels in the fleet at time $t, B D I_{t}$ is the BDI freight index and $S_{t}$ is sentiment. In the demand function, $D_{t}$ stands for the demand proxy of total goods transported, while $\operatorname{Prod}_{t}$ is the total of all industrial and production indices employed in the study. The use of these supply and demand variables are in line with Michail and Melas (2020).

To consider something a true supply-demand equation, a clear measure of both the supply and the demand needs to be available. In the case of shipping, supply is straightforward, and it relates to the number of available vessels, regardless of whether these are hired or not. In general, the idea is that a larger number of vessels would result in more shipowners competing for the same routes and products, something that would push prices lower.

Concerning demand, however, one needs to proxy for the willingness of charterers to employ a vessel. While no such data will ever be available, one could proxy this using the quantity of goods transported. The idea behind this is that the charterers' willingness to transport changes every year, as the factors that affect this willingness (which may be unobservable, such as cultural characteristics, marketing or preferences) also change. 
Thus, while we, by definition, cannot observe the unobservable, we can instead rely on the end-product, which in this case, is the quantity of transported goods.

Furthermore, to account for the fact that shipping is a derived demand system, and hence demand for shipping is driven by demand for other goods, we also employed industrial production for the main industrial regions (US, China, Europe) to account for this. Given that shipping is related to the goods and not the services trade, industrial production better captures the shipping-related goods trade than employing the overall GDP figure. Furthermore, to capture any potential income-related effects from demand (i.e., as income rises, demand also increases), we also employed the US real personal consumption expenditure (PCE).

In both supply and demand, the researcher would require a common price proxy, which is expected to have a positive relationship with the former, and a negative one with the latter. In both cases, the price proxy would be the price of the contract, i.e., the freight rate. This can be easily proxied by the Baltic Dry Index (BDI), which serves as the equilibrium between supply and demand. ${ }^{3}$

In both cases, demand and supply equations need, other than the BDI as the price proxy and the various demand drivers (given that the derived demand nature of shipping), a variable to capture the market's attitude at each point in time. As mentioned before, sentiment is a variable that acts as a catalyst for both the supply and demand functions and eventually for their equilibrium price. A positive sentiment will lead shipowners to either ask for higher prices or to try and negotiate their services for the spot market, given that they would expect that freight rates will increase in the future. On the contrary, a negative sentiment will lead shipowners to be more prudent and to try to hire their vessels for longer periods. To this end, the sentiment proxy is used, as described in the previous section.

Moving to the estimation, the 3SLS setup can be viewed as a system of equations which are stacked, such that:

$$
y_{m}=Z_{m} B_{m}+\epsilon_{m}
$$

where the elements in $Z_{m}$ represent both endogenous and exogenous variables in the equations, and $m=1, \ldots, M$. An important assumption here is that there is no correlation between the disturbances of the equations (i.e., that $E(\epsilon)=0$ and $E\left(\epsilon \epsilon^{\prime}\right)=\Sigma$ ).

The first stage of the 3SLS regression deals with estimating the values of the endogenous variables on the basis of the instruments provided. The values are derived as the predictions from a linear regression of each endogenous variable on all exogenous variables in the system (i.e., the $\hat{y}$ from a usual regression estimate). As such, if the matrix of all exogenous variables is defined as $X$, then:

$$
\hat{z}_{i}=X\left(X^{\prime} X\right)^{-1} X^{\prime} z_{i}
$$

for every $i$, where the collection of individual $\hat{z}_{i}$ would result in the matrix $\hat{Z}$, which contains the instrumented variables for all the regressors. As suggested before, exogenous variables take their actual values and endogenous variables obtain their first-stage predictions, as specified in Equation (1). Given the instrumented variables, one can estimate the coefficients of interest (i.e., the $\hat{B}$ ) using the Aitken (1936) estimator, such that:

$$
\hat{B}=\left[\hat{Z}^{\prime}\left(\Sigma^{-1} \otimes I\right) \hat{Z}\right]^{-1} \hat{Z}^{\prime}\left(\Sigma^{-1} \otimes I\right) y
$$

where a consistent estimator for $\Sigma$ can be obtained via the residuals of the 2SLS estimates of each equation in the system. Hence, replacing $\Sigma$ with $\hat{\Sigma}$, we obtain the 3SLS estimate of the system parameters, while the asymptotic variance-covariance matrix is just the generalized least squares estimator:

$$
V_{\hat{B}}=\left[\hat{Z}^{\prime}\left(\Sigma^{-1} \otimes I\right) \hat{Z}\right]^{-1}
$$


3SLS estimates are usually iterated to reach convergence. The estimates were conducted using Stata statistical software. Before we proceed with the estimation of the functions, the following section offers an overview of the data and their sources.

\subsection{A Look at the Data}

The quantity of transported goods, as offered by the United Nations Conference on Trade and Development (UNCTAD), exists only at an annual frequency, thus limiting the amount of available observations. Thus, while an estimation was conducted and the results are presented in the following section, we also provide an additional estimation using monthly data. As suggested, while the quantity of transported goods is not available on a monthly frequency, we need to resort to a "pseudo" supply and demand model, where the supply side is still proxied by the number of vessels (in DeadWeight Tonnes DWT) but the demand side is proxied by the freight rate. Thus, while this estimation is not a clear illustration of supply and demand, it does help separate demand and supply effects from the BDI and, as such, provides a robustness check on the findings based on the annual data. Furthermore, sentiment is calculated on a monthly basis in accordance with Papapostolou et al. $(2014,2016)$ and the year average of the latter observations is used in our year analysis.

With regard to the data sources for the variables employed in the estimation, we obtained monthly data for the number of dry bulk vessels, the Baltic Dry Index (BDI) and the ratios used for the computation of sentiment from Clarksons Shipping Intelligence database. The European Union, US and China industrial production data, as well as the US personal consumption expenditure (PCE) were obtained from the Federal Reserve of St. Louis Database and Eurostat. UNCTAD was the source for the seaborne trade in dry bulk shipping. In all cases, monthly data were aggregated to reach annual data. The data ranged from 1995 to 2017 for the annual data, and from March 1995 to April 2018 for the monthly data. All data is in log first-difference form. Further information concerning the variables examined can be found in Appendix I, while Table 1 provides the descriptive statistics of the variables.

Table 1. Descriptive statistics.

\begin{tabular}{cccccccc}
\hline & BDI & Sentiment & China_Ind & EU_Ind & US_Ind & US_PCE & Vessels \\
\hline Mean & 16.89 & 21.58 & 11.69 & 0.9 & 1.7 & 4.61 & 3.73 \\
Median & -4.04 & 60 & 11.5 & 1.4 & 2.56 & 4.75 & 2.83 \\
Maximum & 381.17 & 7104.03 & 23.2 & 7.96 & 8.54 & 9.02 & 12.8 \\
Minimum & -92.46 & -4387.63 & 1.8 & -19.15 & -15.33 & -3.03 & -1.29 \\
Std. Dev. & 71.96 & 1907.63 & 4.2 & 4.27 & 4.25 & 1.98 & 3.19 \\
Skewness & 1.63 & 1.61 & 0.14 & -2.14 & -1.81 & -1.38 & 1 \\
Kurtosis & 7.31 & 8.38 & 2.2 & 9.51 & 7.33 & 6.45 & 3.51 \\
Jarque-Bera & 35.4 & 48.93 & 8.02 & 67.71 & 35.51 & 28.11 & 47.55 \\
& $(0.00$ & $(0.00)$ & $(0.00)$ & $(0.00)$ & $(0.00)$ & $260)$ & $(0.00)$ \\
\hline Obs & 268 & 268 & 268 & 268 & & 268 & 268 \\
\hline
\end{tabular}

What stands out the most from Table 1 is that, given the nature of the calculation of sentiment via principal components, the values are not in units that can be easily interpreted, given a maximum of 7104 and a minimum of 4387 . However, a positive sentiment value still relates to higher optimism than pessimism, and a negative sentiment value to higher pessimism than optimism. With regard to the rest of the variables, the estimates suggest that freight rates are highly volatile (as per the findings of Theodossiou et al. 2020), while on the other hand, the standard deviation of supply (Vessels) is not large. Following this, the next section proceeds to estimate the supply and demand reduced-form functions. 


\section{Sentiment-Augmented Supply and Demand}

Table 2 provides the estimation results of the supply and demand functions based on the annual data, as obtained from the sources mentioned above. As suggested earlier, while the number of observations is not large, annual estimates allow us to obtain a "purer" estimate of demand, namely the total quantity transported. In Table 2, the first specification shows the supply and demand functions, without the presence of sentiment, while the second column adds the sentiment proxy to the equation.

Table 2. Supply and demand (annual estimates).

\begin{tabular}{|c|c|c|}
\hline & -1 & -2 \\
\hline Supply & \multicolumn{2}{|c|}{ Dependent Variable: Vessels } \\
\hline Vessels $[-1]$ & $\begin{array}{c}1.04^{* * *} \\
(0.01)\end{array}$ & $\begin{array}{c}1.16^{* * *} \\
(0.25)\end{array}$ \\
\hline BDI & $\begin{array}{c}0.04 \\
(0.04)\end{array}$ & $\begin{array}{l}0.05^{* *} \\
(0.03)\end{array}$ \\
\hline Sentiment & & $\begin{array}{c}0.001^{* *} \\
(0.000)\end{array}$ \\
\hline Constant & $\begin{array}{l}-0.21 \\
(1.18)\end{array}$ & $\begin{array}{l}-0.68 \\
(1.04)\end{array}$ \\
\hline $\mathrm{R}$-squared & 0.44 & 0.45 \\
\hline Prob (Chi-squared) & 0.00 & 0.00 \\
\hline Demand & \multicolumn{2}{|c|}{ Dependent Variable: Dry Load } \\
\hline Dry Load $[-1]$ & $\begin{array}{c}-0.579 * * \\
(0.28)\end{array}$ & $\begin{array}{c}-0.559 \text { ** } \\
(0.28)\end{array}$ \\
\hline BDI & $\begin{array}{c}0.04 \\
(0.04)\end{array}$ & $\begin{array}{c}0.04 \\
(0.03)\end{array}$ \\
\hline EU Industrial & $\begin{array}{c}-0.076 \\
(0.33)\end{array}$ & $\begin{array}{l}-0.45 \\
(0.03)\end{array}$ \\
\hline China Industrial & $\begin{array}{c}0.15 \\
(0.166)\end{array}$ & $\begin{array}{c}0.102 \\
(0.155)\end{array}$ \\
\hline US Industrial & $\begin{array}{c}0.920^{* * *} \\
(0.28)\end{array}$ & $\begin{array}{c}0.859 * * * \\
(0.3)\end{array}$ \\
\hline US PCE & $\begin{array}{l}-0.74 \\
(0.71)\end{array}$ & $\begin{array}{c}-0.888 \\
(0.59)\end{array}$ \\
\hline Sentiment & & $\begin{array}{c}-0.000 \\
(0.01)\end{array}$ \\
\hline Constant & $\begin{array}{c}6.26 * \\
(3.5)\end{array}$ & $\begin{array}{l}7.51 \text { * } \\
(12.8)\end{array}$ \\
\hline $\mathrm{R}$-squared & 0.36 & 0.35 \\
\hline Prob (Chi-squared) & 0.06 & 0.01 \\
\hline Observations & 21 & 21 \\
\hline
\end{tabular}

${ }^{*},{ }^{* *}$ and ${ }^{* * *}$ suggest significance at the $10 \%, 5 \%$ and $1 \%$ levels, respectively.

Definitions of the variables can be found in Appendix A.

In specification (1), in the absence of sentiment, the quantity of vessels is only explained via their own lag. In this case, the price proxy (i.e., the BDI) does not appear to be statistically significant. With regard to the demand equation, price does not appear to be a determinant of the dry load equation, while only US industrial production appears to be a significant determinant of the quantity of goods transported. Even though the results appear to be as expected, there does not appear to any linkage between price and quantity in the equations. While this can be justified for demand, given that it is inelastic to changes in price (Stopford 2013), there is no justification as to why this would happen for the supply side.

This issue is resolved once the sentiment variable is included in the estimation. As specification (2) illustrates, the BDI now has the expected positive and significant relationship with the quantity of vessels (at 0.05 ), while sentiment also has a significant positive 
impact on the quantity of vessels on the market. While the impact of sentiment appears to be small at first (at 0.001), it should be remembered that the standard deviation of the series is at 1907, suggesting that the impact would be much higher than originally considered (Table 1).

Of equal important importance is the fact that sentiment has a positive relationship with the quantity of goods transported. In this case, positive sentiment is expected, as mentioned earlier, to encourage shipowners to either ask for higher charter rates or try and negotiate their services for the spot market. As the results show, however, this further builds into the shipowners' mentality, as it appears that expectations over improved market conditions translate into more vessels entering the market, either by reducing the idle fleet or by higher orders.

Hence, it is only reasonable to reach the conclusion that positive sentiment not only brings ships from lay up into operation, but could also mean that shipowners proceed with orders for new vessels. This is also intuitively appealing, given that it is more than justified for shipowners to expect better market conditions in the future before placing an order that could take 2-3 years to complete. As a result, this would lead to lower freight rates, hence confirming the supply and demand relationship (see also Table 3 where BDI is used as a short-term proxy).

Table 3. Supply and demand (monthly estimates).

\begin{tabular}{|c|c|c|}
\hline & -1 & -2 \\
\hline Supply & \multicolumn{2}{|c|}{ Dependent Variable: Vessels } \\
\hline Vessels $[-1]$ & $\begin{array}{c}1.01^{* * *} \\
(0.01)\end{array}$ & $\begin{array}{c}1.01^{* * *} \\
(0.01)\end{array}$ \\
\hline BDI & $\begin{array}{c}0.002^{* * *} \\
(0.00)\end{array}$ & $\begin{array}{c}0.002 * * * \\
(0.00)\end{array}$ \\
\hline Sentiment & & $\begin{array}{c}0.002 * * \\
(0.001)\end{array}$ \\
\hline Constant & $\begin{array}{c}-0.07^{* * *} \\
(0.03)\end{array}$ & $\begin{array}{c}-0.07^{* * *} \\
(0.03)\end{array}$ \\
\hline $\mathrm{R}$-squared & 0.99 & 0.99 \\
\hline Prob (Chi-squared) & 0.00 & 0.00 \\
\hline Demand & \multicolumn{2}{|c|}{ Dependent Variable: BDI } \\
\hline BDI $[-1]$ & $\begin{array}{c}0.816^{* * *} \\
(0.03)\end{array}$ & $\begin{array}{c}0.820 * * * \\
(0.03)\end{array}$ \\
\hline Vessels & $\begin{array}{c}-2.74^{* * * *} \\
(0.89)\end{array}$ & $\begin{array}{c}-2.79 * * * \\
(0.89)\end{array}$ \\
\hline EU Industrial & $\begin{array}{c}1.03 \\
(0.79)\end{array}$ & $\begin{array}{l}1.07 \\
(0.8)\end{array}$ \\
\hline China Industrial & $\begin{array}{c}2.31^{* * *} \\
(0.58)\end{array}$ & $\begin{array}{c}2.25^{* * *} \\
(0.57)\end{array}$ \\
\hline US Industrial & $\begin{array}{l}-0.55 \\
(0.83)\end{array}$ & $\begin{array}{l}-0.77 \\
(0.85)\end{array}$ \\
\hline US PCE & $\begin{array}{l}-3.01 \\
(2.12)\end{array}$ & $\begin{array}{l}-3.15 \\
(2.11)\end{array}$ \\
\hline Sentiment & & $\begin{array}{c}-0.225 \text { * } \\
(0.11)\end{array}$ \\
\hline Constant & $\begin{array}{c}0.3 \\
(10.1)\end{array}$ & $\begin{array}{c}2.15 \\
(10.1)\end{array}$ \\
\hline $\mathrm{R}$-squared & 0.78 & 0.79 \\
\hline Prob (Chi-squared) & 0.00 & 0.00 \\
\hline Observations & 267 & 267 \\
\hline
\end{tabular}

${ }^{*}{ }^{* *}$ and ${ }^{* * *}$ suggest significance at the $10 \%, 5 \%$ and $1 \%$ levels, respectively. 
Furthermore, this relationship between sentiment and the supply of vessels also makes sense during a recession or other market distress period. In such times, the price impact would drive the supply of vessels lower, but if sentiment improves, and despite the fact that prices are low, shipowners could start to bring back their vessels into the market, thus increasing the overall vessel supply. Similarly, in times of booming prices, it could be the case the shipowners are skeptical about the future. In such a scenario, the availability of vessels would decline as sentiment drops. As expected, sentiment has no impact on the demand for seaborne trade. Thus, our results enhance the existing literature on contrarian investment strategies (Park and Sabourian 2011; Papapostolou et al. 2014).

The findings support and enhance those of Greenwood and Hanson (2015), Melas (2019) and Moutzouris and Nomikos (2020) in the extrapolation of fundamentals literature, given that they empirically support the view that sentiment has a strong impact on vessel supply, irrespective of the current market trends.

Moving on to Table 3, and the monthly estimates, it appears that, in general, these are broadly in line with the annual results. In particular, price (BDI) appears to have a positive and significant relationship with the supplied quantity, while sentiment is also revealed to have a positive impact, for the reasons and with the implications presented above.

As suggested in the previous section, the absence of an available series at a monthly frequency prevents us from estimating a proper demand curve. As such, we instead use the system to estimate the determinants of BDI, which also include supply and demand factors. The results appear to be intuitively appealing and qualitatively similar to the annual estimates. In particular, vessels have the expected negative relationship with the $\mathrm{BDI}$, given that the higher the available supply, the lower the equilibrium price will be, ceteris paribus.

In the short term, as the monthly indicators suggest, China's industrial production can explain more of the variance in the BDI, perhaps due to the increased importance of the country in the global landscape over recent years, even though this importance is likely limited to the last few periods of time. Importantly, sentiment appears to be negatively related with the BDI, even though only weakly significant. The result is as expected, given that higher sentiment would cause an increase in the supply of vessels, thus implicitly increasing supply and thus lowering the price. Furthermore, the results from Table 2 also support the findings of Papapostolou et al. (2014), given that higher than usual sentiment can be a bad sign for future vessel freight rates (given that it implies more vessels and thus lower freight rates), while lower than usual sentiment may potentially be interpreted as a positive signal.

Definitions of the variables can be found in Appendix A.

Overall, the results suggest that, while the standard postulates of economic theory hold (i.e., that prices have a positive relationship with supply and a negative one with demand), sentiment also has a significant effect on the quantity of available vessels, suggesting that a positive view about the market could bring vessels from lay ups and also increase orders. This suggests that a discounting effect also exists in the shipping market, albeit indirectly, with sentiment working its way to an impact on price through its impact on the supply of vessels.

The current findings build on a conundrum in the literature regarding whether the efficient market hypothesis (Malkiel and Fama 1970) holds for the shipping industry, and thus whether arbitrage opportunities are non-existing. Unlike Ådland (2000) and Ådland and Koekebakar (2004), we verify that sentiment is an important variable in the formation of the market equilibrium, and thus affects market fundamentals (for similar results on the matter, see Kavussanos and Alizadeh 2002; Hale and Vanags 1992; and Glen 1997). This behavior is justified in both boom as well as distress periods, where shipowners want to purchase or sell vessels not just on the basis of how the market behaves at that point in time, but also on the basis of their view about the market's future. 


\section{Conclusions}

In this paper, we presented extended empirical estimates of the supply and demand functions in shipping. Furthermore, we augmented these functions with sentiment, which appears to have a significant impact on supply. The results suggest that, according to economic theory, a positive relationship between supply and prices (freight rates-BDI) exists, and a negative one exists between demand and prices. Sentiment has a positive impact on the supply of vessels, suggesting that a positive view about the market's future affects it today, as expectations build into the mentality of shipowners, translating into more vessels being put into the market. Hence, it appears that discounting is also present in shipping markets, similar to that in financial ones.

The intuition behind this situation is straightforward: positive sentiment not only brings ships from lay up into operation, but could also mean that shipowners proceed with orders for new vessels. This is also intuitively appealing, given that it is more than justified for shipowners to anticipate better market conditions in the future before placing an order that could take 2-3 years to complete. Furthermore, the relationship between sentiment and the supply of vessels is also reasonable during a recession or other market distress period. In such times, the price impact may drive the supply of vessels lower, but, as sentiment improves, and despite the fact that prices are low, shipowners may start to bring back their vessels into the market, thus increasing the overall vessel supply. Similarly, in times of booming prices, it could be the case that shipowners are skeptical about the future. In such a scenario, the availability of vessels would decline as sentiment drops.

The results provide an important insight into the shipping market, as they are the first to confirm that market sentiment plays an important role in supply and demand functions. However, our research reveals certain limitations, the most important being the lack of more detailed data, as well as a longer time series. This would allow for the use of ton-miles as a demand variable, rather than simply the quantity transported. As such, future studies should also address the topic by employing higher frequency data.

Author Contributions: Both authors contributed equally to all sections of the article. All authors have read and agreed to the published version of the manuscript.

Funding: This research received no external funding.

Institutional Review Board Statement: Not applicable.

Informed Consent Statement: Not applicable.

Data Availability Statement: Please see variable appendix for data and sources.

Conflicts of Interest: The authors declare no conflict of interest.

Appendix A. Description of Variables

\begin{tabular}{cccc}
\hline Variable & Description & Source & Units of Measurement \\
\hline BDI & Baltic Dry Index. & $\begin{array}{c}\text { Clarksons Shipping } \\
\text { Intelligence Network }\end{array}$ & Index \\
Vessels & $\begin{array}{c}\text { Total bulk carrier fleet } \\
\text { development. }\end{array}$ & $\begin{array}{c}\text { Clarksons Shipping } \\
\text { Intelligence Network }\end{array}$ & $\begin{array}{c}\text { Deadweight tonnage of } \\
\text { the existing fleet (DWT) }\end{array}$ \\
Dry Load & $\begin{array}{c}\text { Metric tons of dry cargo that has } \\
\text { been loaded worldwide in a year t. }\end{array}$ & $\begin{array}{c}\text { United Nations Conference on } \\
\text { Trade and Development } \\
\text { (UNCTAD) Statistics }\end{array}$ & Metric tons in millions \\
\hline
\end{tabular}




\begin{tabular}{|c|c|c|c|}
\hline Variable & Description & Source & Units of Measurement \\
\hline Sentiment & $\begin{array}{l}\text { Sentiment constructed in } \\
\text { accordance with Papapostolou et al. } \\
(2014,2016) \text { and based on the } \\
\text { following ratios: } \\
\text { - } \quad \text { net contracting; } \\
\text { - } \quad \text { money committed; } \\
\text { - } \quad \text { price per earnings; } \\
\text { - } \quad \text { second-hand to newbuildings; } \\
\text { - } \quad \text { turnover. }\end{array}$ & $\begin{array}{l}\text { Clarksons Shipping } \\
\text { Intelligence Network }\end{array}$ & Index \\
\hline Net Contracting & $\begin{array}{l}\text { The net number of vessels that have } \\
\text { been ordered each month when } \\
\text { demolitions and scrapping } \\
\text { is considered. }\end{array}$ & $\begin{array}{l}\text { Clarksons Shipping } \\
\text { Intelligence Network }\end{array}$ & Number of vessels \\
\hline Money Committed & $\begin{array}{l}\text { Amount of dollars spent each } \\
\text { month for newly ordered vessels. }\end{array}$ & $\begin{array}{l}\text { Clarksons Shipping } \\
\text { Intelligence Network }\end{array}$ & USD \\
\hline Price-per-Earnings & $\begin{array}{l}\text { Ratio between the price of a } \\
\text { 5-year-old second-hand vessel and } \\
\text { the equivalent time charter rate } \\
\text { multiplied by } 360 \text { days. }\end{array}$ & $\begin{array}{l}\text { Clarksons Shipping } \\
\text { Intelligence Network }\end{array}$ & Ratio \\
\hline Second-hand-to-Newbuilding & $\begin{array}{l}\text { Ratio between the price of a } \\
\text { 5-year-old second-hand vessel and } \\
\text { a newly built equivalent vessel. }\end{array}$ & $\begin{array}{l}\text { Clarksons Shipping } \\
\text { Intelligence Network }\end{array}$ & Ratio \\
\hline Turnover & $\begin{array}{l}\text { The 12-month average ratio } \\
\text { between the new deliveries of } \\
\text { vessels and the total fleet size. }\end{array}$ & $\begin{array}{l}\text { Clarksons Shipping } \\
\text { Intelligence Network }\end{array}$ & Ratio \\
\hline EU Industrial & $\begin{array}{l}\text { Industrial production in the } \\
\text { European Union. }\end{array}$ & Eurostat & Index \\
\hline China Industrial & Industrial production in China. & Investing.com & Index \\
\hline US Industrial & $\begin{array}{l}\text { Industrial production in the } \\
\text { United States. }\end{array}$ & $\begin{array}{c}\text { Federal Reserve of St. Louis } \\
\text { Database }\end{array}$ & Index \\
\hline US PCE & $\begin{array}{c}\text { Personal consumption expenditure, } \\
\text { United States. }\end{array}$ & $\begin{array}{c}\text { Federal Reserve of St. Louis } \\
\text { Database }\end{array}$ & Index \\
\hline
\end{tabular}

\section{Notes}

1 It should be stated that, while the main variables are the same for the different sub-sectors of the shipping industry (i.e., tankers, dry bulk carriers, containerships, ROROs, LNG and LPG carriers), their significance is not always the same due to the different time frames that vessels are hired for. In the current research, we focus on the dry bulk sector, which is mainly focused on voyage charters (tramp shipping).

2 The interested reader may also refer to Greene (2012) or Davidson and MacKinnon (1993).

3 It should be stated that, additionally, the dry bulk sector acts as a relevant setting given the fact that the Baltic Dry Index is well diversified between time charter parties and spot charter parties (Baltic Exchange 2020).

\section{References}

Ådland, Roar Os, and Siri P. Strandenes. 2007. A Discrete-Time Stochastic Partial Equilibrium Model of the Spot Freight Market. Journal of Transport Economics and Policy 41: 189-218.

Ådland, Roar Os, and Steen Koekebakar. 2004. Market Efficiency in the Second-Hand Market for Bulk Ships. Maritime Economics $\mathcal{E}$ Logistics 6: 197-97. [CrossRef]

Ådland, Roar Os. 2000. Technical Trading Rule Performance in the Second-Hand Asset Markets in Bulk Shipping. Working Paper 2000:4. Bergen: Foundation For Research In Economics And Business Administration, SNF.

Aitken, Alexander C. 1936. IV.--On Least Squares and Linear Combination of Observations. Proceedings of the Royal Society of Edinburgh 55: 42-48. [CrossRef] 
Alexandridis, George, Manolis G. Kavussanos, Chi Y. Kim, Dimitris A. Tsouknidis, and Ilias D. Visvikis. 2018. A Survey of Shipping Finance Research: Setting the Future Research Agenda. Transportation Research Part E: Logistics and Transportation Review 115: 164-212. [CrossRef]

Alizadeh, Amir H., and Nikos K. Nomikos. 2007. Investment Timing and Trading Strategies in the Sale and Purchase Market for Ships. Transportation Research Part B: Methodological 41: 126-43. [CrossRef]

Amemiya, Takeshi. 1977. The Maximum Likelihood and the Nonlinear Three-Stage Least Squares Estimator in the General Nonlinear Simultaneous Equation Model. Econometrica 45: 955-68. [CrossRef]

Angeletos, George-Marios, and Jennifer LaO'. 2013. Sentiments. Econometrica 81: 739-79. [CrossRef]

Baltic Exchange. 2020. Guide to Market Benchmarks. London: Baltic Exchange.

Beenstock, Michael, and Andreas Vergottis. 1989. An Econometric Model Of The World Tanker Market. Journal of Transport Economics and Policy 23: 163-80.

Beenstock, Michael, and Andreas Vergottis. 1993. Econometric Modelling of World Shipping. London: Chapman and Hall.

Benhabib, Jess, Pengfei Wang, and Yi Wen. 2017. Uncertainty and Sentiment-Driven Equilibria. In Sunspots and Non-Linear Dynamics. Edited by Kazuo Nishimura, Alain Venditti and Nicholas C. Yannelis. Cham: Springer, pp. 281-304. [CrossRef]

Bulut, Emrah, Okan Duru, and Shigeru Yoshida. 2013. Market Entry, Asset Returns, and Irrational Exuberance: Asset Management Anomalies in Dry Cargo Shipping. International Journal of Shipping and Transport Logistics 5: 652-67. [CrossRef]

Chiang, Thomas C., and Dazhi Zheng. 2010. An Empirical Analysis of Herd Behavior in Global Stock Markets. Journal of Banking E Finance 34: 1911-21. [CrossRef]

Davidson, Russell, and James G. MacKinnon. 1993. Estimation and Inference in Econometrics. New York: Oxford University Press (OUP).

Deeney, Peter, Mark Cummins, Michael Dowling, and Adam Bermingham. 2015. Sentiment in Oil Markets. International Review of Financial Analysis 39: 179-85. [CrossRef]

Duru, Okan. 2013. Irrational Exuberance, Overconfidence and Short-Termism: Knowledge-to-Action Asymmetry in Shipping Asset Management. The Asian Journal of Shipping and Logistics 29: 43-58. [CrossRef]

Funashima, Yoshito. 2020. Global Economic Activity Indexes Revisited. Economics Letters 193: 109269. [CrossRef]

Gao, Lin, and Stephan Süss. 2015. Market Sentiment in Commodity Futures Returns. Journal of Empirical Finance 33: 84-103. [CrossRef]

Glen, D. R. 1997. The Market for Second-Hand Ships: Further Results on Efficiency Using Cointegration Analysis. Maritime Policy and Management 24: 245-60. [CrossRef]

Greene, William H. 2012. Econometric Analysis, 7th ed. Upper Saddle River: Prentice Hall.

Greenwood, Robin, and Samuel G. Hanson. 2015. Waves in Ship Prices and Investment. The Quarterly Journal of Economics 130: 55-109. [CrossRef]

Hale, Chris, and Alf Vanags. 1992. The Market for Second-Hand Ships: Some Results on Efficiency Using Cointegration. Maritime Policy and Management 19: 31-39. [CrossRef]

Hamilton, James D. 2019. Measuring Global Economic Activity. Journal of Applied Econometrics 36: 293-303. [CrossRef]

Hawdon, D. 1978. Tanker Freight Rates in the Short and Long Run. Applied Economics 10: 203-18. [CrossRef]

Jin, Changha, Gökçe Soydemir, and Alan Tidwell. 2014. The U.S. Housing Market and the Pricing of Risk: Fundamental Analysis and Market Sentiment. Journal of Real Estate Research 36: 187-220. [CrossRef]

Kahneman, By Daniel, Jack L. Knetsch, and Richard H. Thaler. 1986. Fairness as a Constraint on Profit Seeking: Entitlements in the Market. The American Economic Review 76: 728-41.

Kavussanos, Manolis G., and Amir H. Alizadeh. 2002. Efficient Pricing of Ships in the Dry Bulk Sector of the Shipping Industry. Maritime Policy \& Management 29: 303-30. [CrossRef]

Keynes, John Maynard. 1936. The General Theory of Interest, Employment and Money. London: MacMillan.

Kilian, Lutz, and Cheolbeom Park. 2009. The Impact of Oil Price Shocks on the U.S. Stock Market. International Economic Review 50: 1267-87. [CrossRef]

Kilian, Lutz, and Xiaoqing Zhou. 2018. Modeling Fluctuations in the Global Demand for Commodities. Journal of International Money and Finance 88: 54-78. [CrossRef]

Kilian, Lutz. 2009. Not All Oil Price Shocks Are Alike: Disentangling Demand and Supply Shocks in the Crude Oil Market. American Economic Review 99: 1053-69. [CrossRef]

Koopmans, T. C. 1939. Tanker Freight Rates and Tankship Building. An Analyses Cyclical Fluctuations. Haarlem \& London. Available online: https:/ / tidsskrift.dk/nationaloekonomisktidsskrift/article/download/60080/83460?inline=1 (accessed on 18 August 2021).

Krokida, Styliani Iris, Panagiota Makrychoriti, and Spyros Spyrou. 2020. Monetary Policy and Herd Behavior: International Evidence. Journal of Economic Behavior and Organization 170: 386-417. [CrossRef]

Lee, Charles M. C., Andrei Shleifer, and Richard H. Thaler. 1991. Investor Sentiment and the Closed-End Fund Puzzle. The Journal of Finance 46: 75. [CrossRef]

Lee, Taylor Tae-Hwee, and Tsz Leung Yip. 2018. A Cause of Oversupply and Failure in the Shipping Market: Measuring Herding Behavior Effects. Maritime Policy \& Management 45: 995-1006. [CrossRef]

Luo, Meifeng, Lixian Fan, and Liming Liu. 2009. An Econometric Analysis for Container Shipping Market. Maritime Policy and Management 36: 507-23. [CrossRef] 
Malkiel, Burton G., and Eugene F. Fama. 1970. Efficient Capital Markets: A Review of the Theory and Empirical Work. The Journal of Finance 25: 383-417. [CrossRef]

Melas, Konstantinos D. 2019. Three Essays on Behavioural Finance in Shipping Markets. Available online: https://ktisis.cut.ac.cy/ handle/10488/18830 (accessed on 18 August 2021).

Melas, Konstantinos D., and Nektarios A. Michail. 2021. The Relationship between Commodity Prices and Freight Rates in the Dry Bulk Shipping Segment: A Threshold Regression Approach. Maritime Transport Research 2: 100025. [CrossRef]

Melas, Konstantinos D., Photis Panayides, and Dimitris A. Tsouknidis. 2020. Dynamic Volatility Spillovers and Investor Sentiment Components Across Shipping Freight Rates. SSRN Electronic Journal. [CrossRef]

Metaxas, Basil N. 1971. The Economics of Tramp Shipping. London: Athlone Pr.

Michail, Nektarios A. 2020. World Economic Growth and Seaborne Trade Volume: Quantifying the Relationship. Transportation Research Interdisciplinary Perspectives 4: 100108. [CrossRef]

Michail, Nektarios A., and Konstantinos D. Melas. 2019. A Cointegrating Stock Trading Strategy: Application to Listed Tanker Shipping Companies. Journal of Shipping and Trade 4: 9. [CrossRef]

Michail, Nektarios A., and Konstantinos D. Melas. 2020. Quantifying the Relationship between Seaborne Trade and Shipping Freight Rates: A Bayesian Vector Autoregressive Approach. Maritime Transport Research 1: 100001. [CrossRef]

Michail, Nektarios A., and Konstantinos D. Melas. 2021. Newbuilding Orders and Freight Rate Shocks: Evidence from the Containership Market. SSRN Electronic Journal, 1-25. [CrossRef]

Moutzouris, Ioannis C., and Nikos K. Nomikos. 2020. Asset Pricing with Mean Reversion: The Case of Ships. Journal of Banking $\mathcal{E}$ Finance 111: 105708. [CrossRef]

Papapostolou, Nikos C., Nikos K. Nomikos, Panos K. Pouliasis, and Ioannis Kyriakou. 2014. Investor Sentiment for Real Assets: The Case of Dry Bulk Shipping Market. Review of Finance 18: 1507-39. [CrossRef]

Papapostolou, Nikos C., Panos K. Pouliasis, and Ioannis Kyriakou. 2017. Herd Behavior in the Drybulk Market: An Empirical Analysis of the Decision to Invest in New and Retire Existing Fleet Capacity. Transportation Research Part E: Logistics and Transportation Review 104: 36-51. [CrossRef]

Papapostolou, Nikos C., Panos K. Pouliasis, Nikos K. Nomikos, and Ioannis Kyriakou. 2016. Shipping Investor Sentiment and International Stock Return Predictability. Transportation Research Part E: Logistics and Transportation Review 96: 81-94. [CrossRef]

Park, Andreas, and Hamid Sabourian. 2011. Herding and Contrarian Behavior in Financial Markets. Econometrica 79: 973-1026. [CrossRef]

Scarsi, Roberta. 2007. The Bulk Shipping Business: Market Cycles and Shipowners' Biases. Maritime Policy E Management 34: 577-90. [CrossRef]

Schmeling, Maik. 2009. Investor Sentiment and Stock Returns: Some International Evidence. Journal of Empirical Finance 16: $394-408$. Spyrou, Spyros. 2013. Herding in Financial Markets: A Review of the Literature. Review of Behavioral Finance 5: 175-94. [CrossRef]

Stopford, Martin. 2013. Maritime Economics. Maritime Economics, 3rd ed. New York: Routledge. [CrossRef]

Strandenes, Siri Pettersen, and Helen Thanopoulou. 2020. GDP and International Seaborne Trade: Past Trends, Present Breaks and Future Directions. In Geographies of Maritime Transport. Edited by Gordon Wilmsmeier and Jason Monios. Cheltenham: Edward Elgar Publishing, pp. 33-48. [CrossRef]

Syriopoulos, Theodore, and George Bakos. 2019. Investor Herding Behaviour in Globally Listed Shipping Stocks. Maritime Policy E Management 46: 545-64. [CrossRef]

Thaler, Richard. 1985. Mental Accounting and Consumer Choice. Marketing Science 4: 199-214. [CrossRef]

Theodossiou, Panayiotis, Dimitris Tsouknidis, and Christos Savva. 2020. Freight Rates in Downside and Upside Markets: Pricing of Own and Spillover Risks from Other Shipping Segments. Journal of the Royal Statistical Society: Series A (Statistics in Society) 183: 1097-119. [CrossRef]

Tsouknidis, Dimitris A. 2016. Dynamic Volatility Spillovers across Shipping Freight Markets. Transportation Research Part E: Logistics and Transportation Review 91: 90-111. [CrossRef]

Tversky, Amos, and Daniel Kahneman. 1974. Judgment under Uncertainty: Heuristics and Biases. Science 185: 1124-31. [CrossRef]

UNCTAD. 2019. Review of Maritime Transport 2019. Review of Maritime Transport. New York: UN. [CrossRef]

Zannetos, Zenon Soteriou. 1959. The Theory of Oil Tankship Rates. Cambridge: Massachusetts Institute of Technology.

Zellner, Arnold, and Henri Theil. 1962. Three-Stage Least Squares: Simultaneous Estimation of Simultaneous Equations. Econometrica 30: 147-78. [CrossRef] 